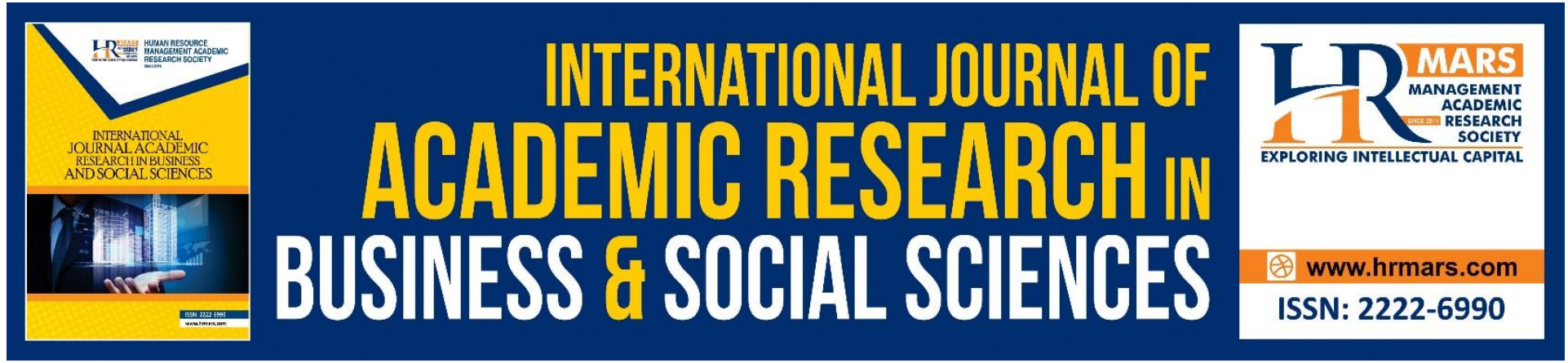

\title{
Organizational Citizenship Behavior of Academic Staff in Malaysian Research Universities
}

\author{
Roshafiza Hassan, Soaib Asimiran, Ramli Basri and Zoharah Omar
}

To Link this Article: http://dx.doi.org/10.6007/IJARBSS/v11-i8/10050～DOI:10.6007/IJARBSS/v11-i8/10050

Received: 16 June 2021, Revised: 21 July 2021, Accepted: 04 August 2021

Published Online: 23 August 2021

In-Text Citation: (Hassan et al., 2021)

To Cite this Article: Hassan, R., Asimiran, S., Basri, R., \& Omar, Z. (2021). Organizational Citizenship Behavior of Academic Staff in Malaysian Research Universities. International Journal of Academic Research in Business and Social Sciences, 11(8), 1086-1101.

Copyright: (c) 2021 The Author(s)

Published by Human Resource Management Academic Research Society (www.hrmars.com)

This article is published under the Creative Commons Attribution (CC BY 4.0) license. Anyone may reproduce, distribute, translate and create derivative works of this article (for both commercial and non-commercial purposes), subject to full attribution to the original publication and authors. The full terms of this license may be seen at: http://creativecommons.org/licences/by/4.0/legalcode

Vol. 11, No. 8, 2021, Pg. 1086 - 1101

Full Terms \& Conditions of access and use can be found at http://hrmars.com/index.php/pages/detail/publication-ethics 


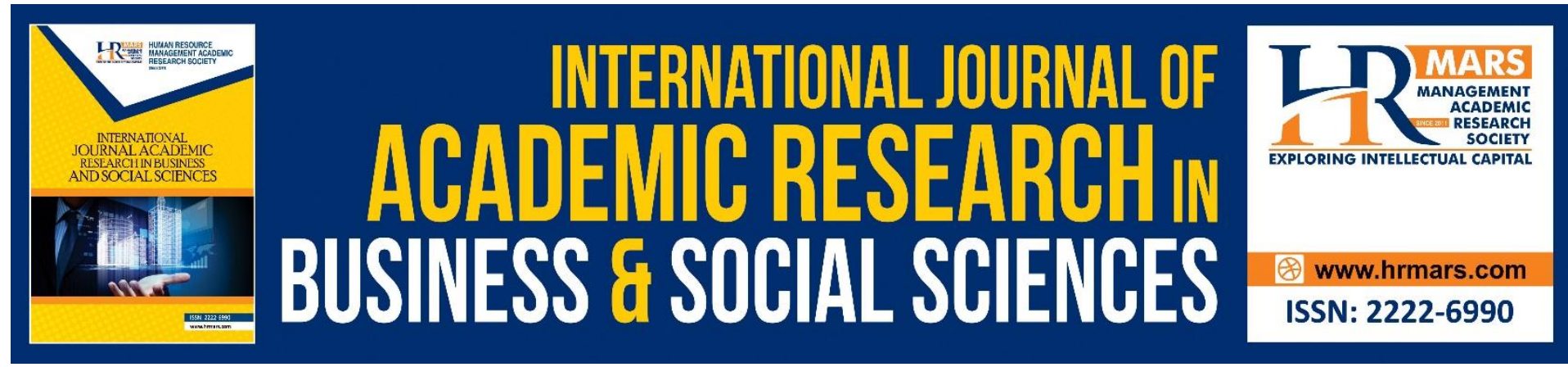

\title{
Organizational Citizenship Behavior of Academic Staff in Malaysian Research Universities
}

\section{Roshafiza Hassan ${ }^{1}$, Soaib Asimiran², Ramli Basri and Zoharah $\mathrm{Omar}^{4}$}

1,2,3 Department of Foundations of Education, ${ }^{4}$ Department of Professional Development and Continuing Education, Faculty of Educational Studies, Universiti Putra Malaysia, 43400 UPM

Serdang Selangor Darul Ehsan, Malaysia

Email: roshafizahassan@gmail.com

\begin{abstract}
This study examined the level of organizational citizenship behavior of academic staff in Malaysian Research Universities. This study employed a quantitative descriptive survey whereby a total of 372 academic staff from five Research Universities were selected as samples for the study. An instrument consisting of 24 items was used to measure the level of academic staff' organizational citizenship behavior at the workplace. The data were collected and analyzed using descriptive statistical tools (frequency, percentage, mean, and standard deviation). The descriptive analysis showed that the level of organizational citizenship behavior (mean $=5.91, S D=0.56$ ) was high. The result of this study also found that the highest dimension of organizational citizenship behavior was contributed by the dimension of courtesy (mean $=6.36, \mathrm{SD}=0.59$ ), followed by the dimension of conscientiousness (mean = $5.96, \mathrm{SD}=0.74$ ). The lowest dimension was contributed by Civic Virtue (mean $=5.55, \mathrm{SD}=$ 0.80). Overall, academic staff' organizational citizenship behavior was confirmed as a significant factor in enhancing institutional development in Malaysian Research Universities. Keywords: Organizational Citizenship Behavior, Academic Staff, Malaysian Research Universities, Higher Education
\end{abstract}

\section{Introduction}

Research University (RU) is an institution that focuses on activities to promote research, development, innovation, and commercialization of products and services. In Malaysia, RUs have been established since early 2006 after the Ministry of Education formed an ad hoc committee comprising researchers from premier universities, purposely to formulate the policy on the establishment of an RU (Nasiibah et al., 2013). To be conferred the title as an $\mathrm{RU}$, selected universities need to go through several eligibility evaluations as required by the appointed evaluators.

To date, five public universities in Malaysia have been conferred the title of Research University (RU). These universities are University of Malaya (UM), Universiti Putra Malaysia (UPM), Universiti Kebangsaan Malaysia (UKM), Universiti Sains Malaysia (USM), and Universiti 
Teknologi Malaysia (UTM). In general, the establishment of RU concentrates on leading the area of research and research development. As driven by the universities' goal to maintain as RUs, academic staff need to work harder and fully utilize their knowledge and skills in performing tasks such as research collaborations, research innovations, research publications, research commercialization, and planning for academic development as well their core activities of teaching and supervising students.

Although academic staff encounter various challenging tasks in their daily routine (Preymann et al., 2016), they are inclined to render ultimate commitments as well as intensive and extensive efforts to the organization. Their commitment as willingness to perform tasks beyond in-role formal job specifications are certainly desired by leaders and organizations. These include working overtime, helping new colleagues, organizing office-wide functions, complying with the rules and regulations, volunteering to change shifts or take over duties, handling students' needs and expectations, and many others regardless of the rewards, compensations, salary increments, or promotions. Organ, Podsakoff, and MacKenzie (2006) identified organizational citizenship behaviors (OCBs) of which employees consider something more than quantifiable in performance appraisals. OCBs are about the individual being selfless and contributes something beyond his or her job scope for the success of the organization.

Citizenship behavior towards the organization is important in predicting employees' sense of belonging and engagement toward the organization. In the context of higher education, the lack of Organizational Citizenship Behaviors (OCBs) among academicians could affect the effectiveness of the institutions. To support this notion, Rose, Miller, and Kacirek (2016) found that a high level of employees' OCBs would result in less complaints and resistance towards the changes by the management. Even though OCBs are difficult to assess in RUs due to some challenges such as governance, autonomy, funding, and academic system (Altbach, 2013), numerous studies have highlighted the significance of OCBs on organizational success. Besides, as RUs are currently striving to achieve academic excellence, therefore it is important to assess the level of OCBs among academics as they serve the needs of the society as well as the implementers of knowledge creation and dissemination.

Employees with OCBs are willing to put extensive effort into their job, have high tolerability in representing the organization, as well as are highly desirable to remain as a member of the respective organizations. Organ, Podsakoff, and MacKenzie (2006) proposed five major domains of OCBs which are altruism, courtesy, conscientiousness, civic virtue, and sportsmanship. As conceptualized by previous literature (Eyupoglu, 2016; Rose et al., 2016; Ueda, 2016; Dirican \& Erdil, 2016; Al-Sharafi \& Rajiani, 2013; Organ et al., 2006), 'altruism' is known as helping behavior which focuses on helping out colleagues in handling tasks, 'courtesy' is about staying up on company policies, while 'conscientiousness' is doing an exceptional job in one's role, 'civic virtue' as an employee's behavior of being kind to colleagues, and finally 'sportsmanship' which emphasizes on employees for not complaining about little inconveniences at the workplace. Essentially, OCBs are about employees' contributions to the organization that go above and beyond the main tasks assigned to them. The term organizational citizenship behavior (OCB) refers to discretionary behaviors that indirectly benefit the colleagues and the organizations which are neither mandated nor compensated by the institution. According to Organ (1988), OCBs are unwritten actions 
between one employee to another or at the group and the organizational level that exceed the written job specifications. Therefore, discretionary behavior is a matter of personal decisions and choices made by the individuals as the negligence is not generally implied as punishable, rather it is not compulsory in the job description requirements. These sorts of behaviors are not specified in the individual's terms of employment contract. Organ, Podsakoff, and Mackenzie (2006) divided the term OCBs into five dimension which are altruism, courtesy, conscientiousness, sportsmanship, and civic virtue as shown in Table 1 below.

Table 1. The Dimension of Organizational Citizenship Behaviors (Organ, Podsakoff, \& MacKenzie, 2006)

\begin{tabular}{|c|c|}
\hline Dimension & Descriptions \\
\hline Altruism & $\begin{array}{l}\text { Behaviors focused at helping colleagues related with the relevant task or } \\
\text { problem at the workplace. }\end{array}$ \\
\hline Courtesy & Behaviors intended at preventing the incidence of work-related problems. \\
\hline Conscientiousness & $\begin{array}{l}\text { Individual's acceptance of the general compliance such as rules, regulations, } \\
\text { and procedure, even when no one is there or keeps an eye on adherence. }\end{array}$ \\
\hline Sportsmanship & $\begin{array}{l}\text { Behaviors which indicate the willingness of people to tolerate the inevitable } \\
\text { inconveniences and impositions of work without complaining. }\end{array}$ \\
\hline Civic Virtue & $\begin{array}{l}\text { Employee's concern about the political life, responsibility, and common } \\
\text { welfare of the organization. }\end{array}$ \\
\hline
\end{tabular}

Overall, these dimensions promote OCBs as voluntarily actions of non-task jobs without any promise of direct return. Ueda (2016) further elaborated altruism and courtesy as behaviors that benefit other people in some ways and indirectly contribute to the organization as well, whereas conscientiousness, sportsmanship, and civic virtue are behaviors related to benefitting the overall or larger organizations, not necessarily to specific people. In the higher education context, Rose, Miller, and Kacirek (2016) had outlined several situations where academic staff exhibit OCBs. For example, when they help colleagues who have strains and difficulties in doing their tasks, preventing things that tarnish the organization's image and reputation, resilient and persevered in doing jobs, avoiding things that tarnish the image of the organization, spending extra time to achieve objectives, attending meetings that are not compulsory, and showing extra concerns about the organization's achievement. OCBs are work-related behaviors keen by the employees, but not related to the formal reward, however, in aggregate, they will build up the organizational performance efficiently and effectively.

OCBs becomes important in Malaysian RUs as it could help academic staff to enhance the performance and achieve the development of the organization. Besides, OCBs would allow academics to enhance their effectiveness and increase the level of productivity. Shanker (2018); Sufean and Chin (2014) found that competition among higher education institutions implies that staff must contribute themselves with a lot of activities in order to meet up with the complex situation and meet the requirement of the competitive global market. Therefore, OCBs could also be a benchmark for the policymakers, management party, and administrators 
in fostering quality academic staff that would create the RUs for better academic service delivery and development through identifying strengths, weaknesses, opportunities, and threats in the organization.

\section{Methodology}

This study intends to:

1. Identify the level of organizational citizenship behavior of academic staff in Malaysian Research Universities.

Q1. What is the level of organizational citizenship behavior of academic staff in Malaysian Research Universities?

2. Identify the highest domain contributed to academic staff' organizational citizenship behavior in Malaysian Research Universities.

Q2. What is the highest domain contributed to academic staff' organizational citizenship behavior in Malaysian Research Universities?

\section{1) Sample}

There are various methods can be employed in determining the sample size to represent the population of the study. Creswell (2014) suggest that sampling size determination can be done based on conformity and flexibility in handling the process of collecting the data. This research will be operating using a stratified random sampling (proportional) procedure in ensuring the adequacy and representativeness of the selected sample (Gay, Mills \& Airasian, 2012) where the samples chosen from the populations were limited to academic staff in similar faculty within universities.

Stratified random sampling involves a sampling of a population subdivided into smaller groups called strata. Therefore, stratified random sampling encompasses taking random samples from stratified groups, in proportion to the population. This technique is a more precise metric since it is a better representation of the overall population (Creswell, 2014; Hair et al., 2014). The sample is limited to 372 respondents due to time and financial constraints. Besides, this procedure is suitable to bridge the gap in gaining respondents' understanding from the perspective of consistency of the data.

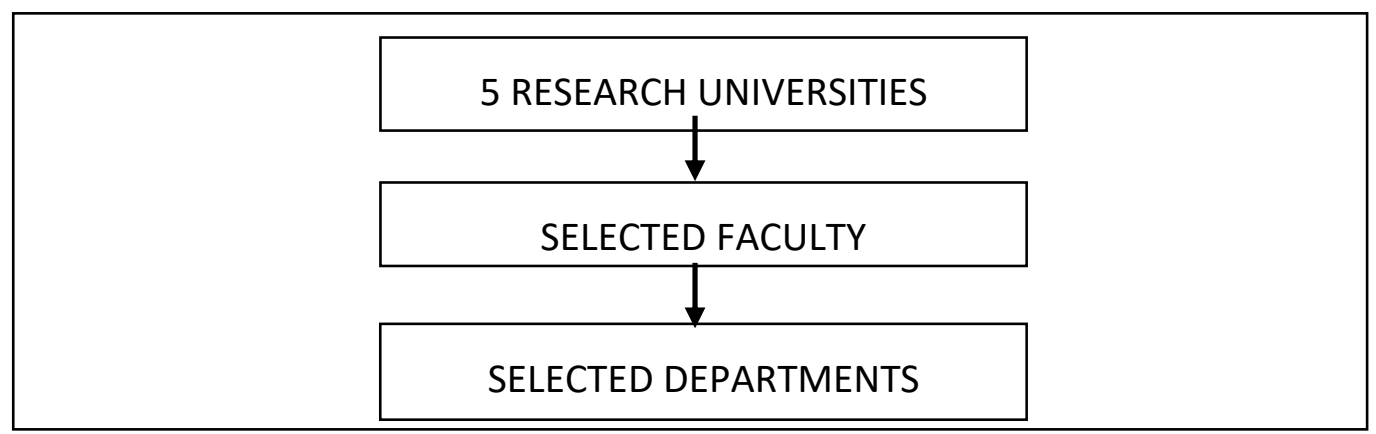

Figure 1. Stratified Random Sampling Procedure for Selecting Academic Staff in Five Research Universities, Malaysia

Figure 1 presents the steps in selecting a sample of the study. This study involves all five public universities that have been conferred as a Research University (RU) in Malaysia. The selection of faculty has been made according to the similarities of characteristics and inclusive between the institutions (universities). Then, the researcher will select each department to represent 
their group (faculty). Eventually, selected academic staff will be chosen in stratified random (proportion) as respondents of the study (departments). Therefore, a total sample consists of 372 academic staff from five Research Universities in Malaysia were selected in this study.

2) Tool

This research adopted the dimensions of organizational citizenship behaviors (OCBs) scale suggested by Podsakoff, MacKenzie, Moorman, and Fetter (1990). This questionnaire consists of 24 items regarding the information related to OCBs namely altruism, courtesy, civic virtue, conscientiousness, and sportsmanship. Academic staff is required to answer to the extent to which they exhibit OCBs in a 7-point scale ( 1 = Strongly Disagree, $7=$ Strongly Agree) of how frequently they would participate in the identified behaviors. The questionnaire has a high construct validity (evaluated by confirmatory factor analysis), and each of the five sub-scales has a good level of reliability. The result of confirmatory factor analysis (CFA) of this scale $\alpha=$ 0.94 (Podsakoff et al., 1990) was good and established.

3) Validity and Reliability of Research Instruments

The validity of the instrument was evaluated using content validity methods. The content validity was used to determine the relevance of the items in the instrument. To determine the content validity, two experts were chosen as a validator for the instrument of this study. The criteria for selecting experts included knowledge and experience related to the area as well as relevant training (Gay, Mills \& Airasian, 2012). Therefore, experts with more than 5 years of experience in the unit and were familiar with the concepts of Organizational Citizenship Behavior were selected for this study. The experts had to confirm that the items were valid to be used in the study.

A suggested approach to CFA proceeds through the review of relevant theory and research literature to support the model specification, specify a model (diagram, equations), determine model identification (if unique values can be found for parameter estimation, the number of degrees of freedom, degree of freedom), collect data, conduct preliminary descriptive statistical analysis (scaling, missing data, collinearity issues, outlier detection), estimate parameters in the model, assess model fit, present and interpret the results. Kline (2011) was interpreted the value of Cronbach Alpha in assessing the reliability of the construct as below:

Table 2. An Interpretation of Cronbach Alpha in Assessing Reliability of the Construct and Item

\begin{tabular}{cc}
\hline \hline Cronbach Alpha $(\boldsymbol{\alpha})$ & Interpretation \\
\hline \hline$<0.50$ & Not reliable \\
0.70 & Adequate \\
0.80 & Very good \\
0.90 & Excellent \\
\hline \hline
\end{tabular}

Source: Kline (2011) 
The table shows that it is not reliable and difficult to justify a proposed indicator of a construct in exploratory research if its reliability were less than 0.50 because in that case, more than 50 percent of its variance would be an error variance (Kline, 2011). Since the construct reliability test aims to maximize $\alpha$, researchers generally accept values of the instrument with construct reliability above 0.70 as demonstrating that a scale is internally consistent (Hair et al., 2014). This study practically agreed with this suggestion that 0.70 is practically adequate in ensuring that the construct is reliable to be employed. In general, construct validity measures the validity of the instrument. Hair, Black, Babin, and Anderson (2014) clarified construct validity as the extent to which a set of measured variables represents the theoretical latent construct those variables are designed to measure.

\section{Results}

Q1. What is the level of organizational citizenship behavior of academic staff in Malaysian Research Universities?

This section exhibits a descriptive analysis of percentage, mean scores, standard deviation, and the level of organizational citizenship behaviors (OCBs) as per item based on the dimensions. A total of 24 items with a 7-point scale were used to measure the level of OCBs in each dimension as performed by academic staff. The findings are presented based on the dimensions.

Table 3a presents the dimension of altruism. The result showed that all items measuring the dimension scored high. The item "I am always ready to lend a helping hand to those around me" contributed the highest mean score of 6.17 and standard deviation (SD) $=0.89$ followed by the item "I am willing to help others who have work-related problems" with mean $=6.16$ and SD $=0.83$ and "I help orient new people even though it is not required" with mean $=5.65$ and SD $=1.11$. The second-lowest item was "I help colleagues who have a heavy workload" with mean $=5.44$ and $S D=1.20$ while the lowest showed by the item "I help colleagues who have been absent" with mean $=5.18$ and $S D=1.42$. 
Table 3aDescriptive Analysis of OCBs (D1: Altruism)

\begin{tabular}{|c|c|c|c|c|c|c|c|c|c|c|}
\hline \multirow{2}{*}{ Item } & \multicolumn{7}{|c|}{ Frequency and Percentage (\%) } & \multirow[t]{2}{*}{ Mean } & \multirow[t]{2}{*}{ SD } & \multirow[t]{2}{*}{ Level } \\
\hline & 1 & 2 & 3 & 4 & 5 & 6 & 7 & & & \\
\hline $\begin{array}{l}\text { I help } \\
\text { colleagues who } \\
\text { have a heavy }\end{array}$ & $\begin{array}{c}4 \\
(1.1)\end{array}$ & $\begin{array}{c}5 \\
(1.3)\end{array}$ & $\begin{array}{c}9 \\
(2.4)\end{array}$ & $\begin{array}{c}44 \\
(11.8)\end{array}$ & $\begin{array}{c}137 \\
(36.8)\end{array}$ & $\begin{array}{c}91 \\
(24.5)\end{array}$ & $\begin{array}{c}82 \\
(22)\end{array}$ & 5.44 & 1.2 & High \\
\hline $\begin{array}{l}\text { I am always } \\
\text { ready to lend a } \\
\text { helping hand to } \\
\text { those around } \\
\text { heln orient }\end{array}$ & - & $\begin{array}{c}1 \\
(0.3)\end{array}$ & $\begin{array}{c}3 \\
(0.8)\end{array}$ & $\begin{array}{c}12 \\
(3.2)\end{array}$ & $\begin{array}{c}55 \\
(14.8)\end{array}$ & $\begin{array}{c}144 \\
(38.7)\end{array}$ & $\begin{array}{c}157 \\
(42.2)\end{array}$ & 6.17 & 0.89 & High \\
\hline $\begin{array}{l}\text { new people } \\
\text { even though it } \\
\text { is not required. }\end{array}$ & - & $\begin{array}{c}3 \\
(0.8)\end{array}$ & $\begin{array}{c}11 \\
(3.0)\end{array}$ & $\begin{array}{c}40 \\
(10.8)\end{array}$ & $\begin{array}{c}98 \\
(26.3)\end{array}$ & $\begin{array}{c}126 \\
(33.9)\end{array}$ & $\begin{array}{c}94 \\
(25.3)\end{array}$ & 5.65 & 1.11 & High \\
\hline $\begin{array}{l}\text { colleagues who } \\
\text { have been }\end{array}$ & $\begin{array}{c}10 \\
(2.7)\end{array}$ & $\begin{array}{c}7 \\
(1.9)\end{array}$ & $\begin{array}{c}28 \\
(7.5)\end{array}$ & $\begin{array}{c}50 \\
(13.4)\end{array}$ & $\begin{array}{c}112 \\
(30.1)\end{array}$ & $\begin{array}{c}95 \\
(25.5)\end{array}$ & $\begin{array}{c}70 \\
(18.8)\end{array}$ & 5.18 & 1.42 & High \\
\hline $\begin{array}{l}\text { I am willing to } \\
\text { help others } \\
\text { who have } \\
\text { work-related }\end{array}$ & - & - & - & $\begin{array}{l}11 \\
(3)\end{array}$ & $\begin{array}{c}70 \\
(18.8)\end{array}$ & $\begin{array}{c}139 \\
(37.4)\end{array}$ & $\begin{array}{c}152 \\
(40.9)\end{array}$ & 6.16 & 0.83 & High \\
\hline OVERALL & & & & & & & & 5.72 & 0.81 & High \\
\hline
\end{tabular}

Overall, the results showed a high level of altruism as perceived by academic staff (mean = $5.72 ;$ SD $=0.81$ ). It shows that academic staff were concerned for their colleagues and ready to devote to the good of others.

Table 3bDescriptive Analysis of OCBs (D2: Courtesy)

\begin{tabular}{|c|c|c|c|c|c|c|c|c|c|}
\hline \multirow{2}{*}{ Item } & \multicolumn{6}{|c|}{ Frequency and Percentage (\%) } & \multirow{2}{*}{ Mean } & \multirow{2}{*}{ SD } & \multirow{2}{*}{ Level } \\
\hline & 1 & 2 & 4 & 5 & 6 & 7 & & & \\
\hline $\begin{array}{l}\text { I try to avoid creating } \\
\text { problems for co-workers. }\end{array}$ & - & - & $\begin{array}{c}6 \\
(1.6)\end{array}$ & $\begin{array}{c}20 \\
(5.4)\end{array}$ & $\begin{array}{c}96 \\
(25.8)\end{array}$ & $\begin{array}{c}250 \\
(67.2)\end{array}$ & 6.59 & 0.67 & High \\
\hline $\begin{array}{l}\text { I consider the impact of my } \\
\text { actions on co-workers. }\end{array}$ & - & $\begin{array}{cc}- & 3 \\
& (0.8)\end{array}$ & $\begin{array}{c}10 \\
(2.7)\end{array}$ & $\begin{array}{c}42 \\
(11.3)\end{array}$ & $\begin{array}{c}139 \\
(37.4)\end{array}$ & $\begin{array}{c}178 \\
(47.8)\end{array}$ & 6.29 & 0.83 & High \\
\hline $\begin{array}{l}\text { I respect the rights of } \\
\text { people that work with me. }\end{array}$ & - & - & $\begin{array}{c}1 \\
(0.3)\end{array}$ & $\begin{array}{c}31 \\
(8.3)\end{array}$ & $\begin{array}{c}115 \\
(30.9)\end{array}$ & $\begin{array}{c}225 \\
(60.5)\end{array}$ & 6.52 & 0.66 & High \\
\hline $\begin{array}{l}\text { I take steps carefully to } \\
\text { avoid problems with other }\end{array}$ & - & $\begin{array}{c}-\quad 2 \\
(0.5)\end{array}$ & $\begin{array}{l}11 \\
(3)\end{array}$ & $\begin{array}{c}33 \\
(8.9)\end{array}$ & $\begin{array}{c}138 \\
(37.1)\end{array}$ & $\begin{array}{c}188 \\
(50.5)\end{array}$ & 6.34 & 0.80 & High \\
\hline $\begin{array}{l}\text { I am mindful of how my } \\
\text { behaviors affect other } \\
\text { people's jobs. }\end{array}$ & $\begin{array}{c}1 \\
(0.3)\end{array}$ & $\begin{array}{cc}2 \\
-\quad(0.5)\end{array}$ & $\begin{array}{c}19 \\
(5.1)\end{array}$ & $\begin{array}{c}77 \\
(20.7)\end{array}$ & $\begin{array}{l}119 \\
(32)\end{array}$ & $\begin{array}{c}154 \\
(41.4)\end{array}$ & 6.08 & 0.97 & High \\
\hline OVERALL & & & & & & & 6.36 & 0.59 & High \\
\hline
\end{tabular}

The dimension of courtesy was measured using five items. The result of the analysis showed that all items generated high scores. The item "I try to avoid creating problems for co- 
workers" contributed to the highest level of OCBs in this dimension with mean $=6.59, \mathrm{SD}=$ 0.67. The second item in this dimension was "I respect the rights of people that work with me" with mean $=6.52, \mathrm{SD}=0.66$, followed by "I take steps carefully to avoid problems with other workers" with mean $=6.34, \mathrm{SD}=0.80$ while the item "I consider the impact of my actions on co-workers" revealed mean $=6.29, \mathrm{SD}=0.83$. The item "I am mindful of how my behavior affects other people's jobs" demonstrated the lowest level in this dimension with mean $=6.08$ and SD $=0.97$. In general, this dimension showed a high level (mean $=6.36, S D=$ 0.59). The findings indicated that academic staff of the Research Universities, Malaysia were enthusiastic in displaying politeness and good behaviors in their working culture.

Table 3c Descriptive Analysis of OCBs (D3: Civic Virtue)

\begin{tabular}{|c|c|c|c|c|c|c|c|c|c|c|}
\hline \multirow{2}{*}{ Item } & \multicolumn{7}{|c|}{ Frequency and Percentage (\%) } & \multirow[t]{2}{*}{ Mean } & \multirow[t]{2}{*}{ SD } & \multirow[t]{2}{*}{ Level } \\
\hline & 1 & 2 & 3 & 4 & 5 & 6 & 7 & & & \\
\hline $\begin{array}{l}\text { I keep abreast of } \\
\text { changes in the }\end{array}$ & - & $\begin{array}{c}1 \\
(0.3)\end{array}$ & $\begin{array}{c}5 \\
(1.3)\end{array}$ & $\begin{array}{c}30 \\
(8.1)\end{array}$ & $\begin{array}{c}103 \\
(27.7)\end{array}$ & $\begin{array}{c}135 \\
(36.3)\end{array}$ & $\begin{array}{c}98 \\
(26.3 \%)\end{array}$ & 5.77 & 0.99 & High \\
\hline $\begin{array}{l}\text { I attend meetings } \\
\text { that are not } \\
\text { mandatory but are }\end{array}$ & $\begin{array}{c}3 \\
(0.8)\end{array}$ & $\begin{array}{c}3 \\
(0.8)\end{array}$ & $\begin{array}{c}13 \\
(3.5)\end{array}$ & $\begin{array}{c}44 \\
(11.8)\end{array}$ & $\begin{array}{c}92 \\
(24.7)\end{array}$ & $\begin{array}{c}115 \\
(30.9)\end{array}$ & $\begin{array}{c}102 \\
(27.4)\end{array}$ & 5.61 & 1.22 & High \\
\hline $\begin{array}{l}\text { I attend functions } \\
\text { that are not } \\
\text { reauired but help } \\
\text { I read and keep up }\end{array}$ & $\begin{array}{c}8 \\
(2.2)\end{array}$ & $\begin{array}{c}14 \\
(3.8)\end{array}$ & $\begin{array}{c}23 \\
(6.2)\end{array}$ & $\begin{array}{c}66 \\
(17.7)\end{array}$ & $\begin{array}{c}107 \\
(28.8)\end{array}$ & $\begin{array}{l}93 \\
(25)\end{array}$ & $\begin{array}{c}61 \\
(16.4)\end{array}$ & 5.08 & 1.42 & High \\
\hline $\begin{array}{l}\text { with organization } \\
\text { announcements, }\end{array}$ & - & - & $\begin{array}{l}11 \\
(3)\end{array}$ & $\begin{array}{c}31 \\
(8.3)\end{array}$ & $\begin{array}{c}106 \\
(28.5)\end{array}$ & $\begin{array}{c}128 \\
(34.4)\end{array}$ & $\begin{array}{c}96 \\
(25.8)\end{array}$ & 5.72 & 1.03 & High \\
\hline OVERALL & & & & & & & & 5.55 & 0.8 & High \\
\hline
\end{tabular}

The domain of civic virtue was measured by four items. The result exhibited that all items scored high. The highest item was "I keep abreast of changes in the organization" (mean = $5.77, \mathrm{SD}=0.99$ ). The item "I read and keep up with organization announcements, memos, and so on" indicated mean $=5.72, S D=1.03$ ), which came second. The result also displayed two items with the lowest scores which were "I attend meetings that are not mandatory but are considered important" (mean $=5.61, S D=1.22$ ) and "I attend functions that are not required but help the company image" (mean $=5.08, S D=1.42$ ). Overall, the dimension of civic virtue score was high (mean $=5.55, \mathrm{SD}=0.80$ ). From this result, it showed that academic staff in Malaysian Research Universities were devoted to the success of the community. They believed that good citizens who sacrificed for others would result in a successful society. 
Table 3dDescriptive Analysis of OCBs (D4: Conscientiousness)

\begin{tabular}{|c|c|c|c|c|c|c|c|c|c|c|}
\hline \multirow{2}{*}{ Item } & \multicolumn{7}{|c|}{ Frequency and Percentage (\%) } & \multirow[t]{2}{*}{ Mean } & \multirow[t]{2}{*}{ SD } & \multirow[t]{2}{*}{ Level } \\
\hline & 1 & 2 & 3 & 4 & 5 & 6 & 7 & & & \\
\hline $\begin{array}{l}\text { I believe in giving } \\
\text { an honest day's } \\
\text { work for an honest }\end{array}$ & - & - & - & $\begin{array}{c}6 \\
(1.6)\end{array}$ & $\begin{array}{c}30 \\
(8.1)\end{array}$ & $\begin{array}{c}86 \\
(23.1)\end{array}$ & $\begin{array}{c}250 \\
(67.2)\end{array}$ & 6.56 & 0.71 & High \\
\hline $\begin{array}{l}\text { My attendance at } \\
\text { work is above the }\end{array}$ & $\begin{array}{c}1 \\
(0.3)\end{array}$ & $\begin{array}{c}2 \\
(.5)\end{array}$ & $\begin{array}{c}6 \\
(1.6)\end{array}$ & $\begin{array}{c}44 \\
(11.8)\end{array}$ & $\begin{array}{c}97 \\
(26.1)\end{array}$ & $\begin{array}{c}114 \\
(30.6)\end{array}$ & $\begin{array}{c}108 \\
(29.0)\end{array}$ & 5.71 & 1.11 & High \\
\hline $\begin{array}{l}\text { I do not take extra } \\
\text { breaks. }\end{array}$ & $\begin{array}{c}4 \\
(1.1)\end{array}$ & $\begin{array}{c}8 \\
(2.2)\end{array}$ & $\begin{array}{c}17 \\
(4.6)\end{array}$ & $\begin{array}{c}60 \\
(16.1)\end{array}$ & $\begin{array}{c}75 \\
(20.2)\end{array}$ & $\begin{array}{c}93 \\
(25.0)\end{array}$ & $\begin{array}{c}115 \\
(30.9)\end{array}$ & 5.51 & 1.40 & High \\
\hline $\begin{array}{l}\text { I obey company } \\
\text { rules and policies } \\
\text { even when no }\end{array}$ & - & $\begin{array}{c}2 \\
(.5)\end{array}$ & $\begin{array}{c}2 \\
(.5)\end{array}$ & $\begin{array}{c}17 \\
(4.6)\end{array}$ & $\begin{array}{c}61 \\
(16.4)\end{array}$ & $\begin{array}{c}131 \\
(35.2)\end{array}$ & $\begin{array}{c}159 \\
(42.7)\end{array}$ & 6.13 & 0.95 & High \\
\hline $\begin{array}{l}\text { nno ic watrhing } \\
\text { I am one of the } \\
\text { most conscientious } \\
\text { employees. }\end{array}$ & $\begin{array}{c}1 \\
(.3)\end{array}$ & - & $\begin{array}{c}4 \\
(1.1)\end{array}$ & $\begin{array}{c}26 \\
(7.0)\end{array}$ & $\begin{array}{c}91 \\
(24.5)\end{array}$ & $\begin{array}{c}131 \\
(35.2)\end{array}$ & $\begin{array}{c}119 \\
(32.0)\end{array}$ & 5.89 & 1.00 & High \\
\hline OVERALL & & & & & & & & 5.96 & 0.74 & High \\
\hline
\end{tabular}

In regards to the dimension of conscientiousness, the result revealed that all items achieved high scores. Out of five items, "I believe in giving an honest day's work for an honest day's pay" contributed to the highest mean $(6.56, S D=0.71)$, then followed by the item "I obey company rules and policy even when no one is watching me" (mean $=6.13, \mathrm{SD}=0.95$. The other items that contributed to this dimension were denoted by "I am one of the most conscientious employees" (mean $=5.89, \mathrm{SD}=1$ ) and "My attendance at work is above the norm" (mean $=5.71, S D=1.11$ ). The lowest item in this dimension was "I do not take extra breaks" (mean $=5.51, S D=1.40$ ). This result showed that academic staff in Research Universities, Malaysia profoundly accepted and obeyed the rules, regulations, and procedures of the organization. 
Table 3eDescriptive Analysis of OCBs (D5: Sportsmanship)

\begin{tabular}{|c|c|c|c|c|c|c|c|c|c|c|}
\hline \multirow{2}{*}{ Item } & \multicolumn{7}{|c|}{ Frequency and Percentage (\%) } & \multirow[t]{2}{*}{ Mean } & \multirow[t]{2}{*}{ SD } & \multirow[t]{2}{*}{ Level } \\
\hline & 1 & 2 & 3 & 4 & 5 & 6 & 7 & & & \\
\hline $\begin{array}{l}\text { I am not the persor } \\
\text { who likes to } \\
\text { complains or } \\
\text { protests the loudes } \\
\text { attracts attention } \\
\text { and service. }\end{array}$ & $\begin{array}{c}2 \\
(.5)\end{array}$ & $\begin{array}{c}11 \\
(3.0)\end{array}$ & $\begin{array}{c}17 \\
(4.6)\end{array}$ & $\begin{array}{c}47 \\
(12.6)\end{array}$ & $\begin{array}{c}60 \\
(16.1)\end{array}$ & $\begin{array}{c}116 \\
(31.2)\end{array}$ & $\begin{array}{c}119 \\
(32.0)\end{array}$ & 5.62 & 1.37 & High \\
\hline $\begin{array}{l}\text { I do not waste time } \\
\text { complaining about } \\
\text { trivial matters. }\end{array}$ & - & $\begin{array}{c}3 \\
(.8)\end{array}$ & $\begin{array}{c}5 \\
(1.3)\end{array}$ & $\begin{array}{c}22 \\
(5.9)\end{array}$ & $\begin{array}{c}66 \\
(17.7)\end{array}$ & $\begin{array}{c}124 \\
(33.3)\end{array}$ & $\begin{array}{c}152 \\
(40.9 \%)\end{array}$ & 6.04 & 1.04 & High \\
\hline $\begin{array}{l}\text { I do not tend to } \\
\text { magnify }\end{array}$ & - & $\begin{array}{c}1 \\
(.3)\end{array}$ & $\begin{array}{c}5 \\
(1.3)\end{array}$ & $\begin{array}{c}14 \\
(3.8)\end{array}$ & $\begin{array}{c}43 \\
(11.6)\end{array}$ & $\begin{array}{c}114 \\
(30.6)\end{array}$ & $\begin{array}{c}195 \\
(52.4)\end{array}$ & 6.28 & 0.94 & High \\
\hline $\begin{array}{l}\text { I always focus on } \\
\text { what is right, } \\
\text { rather than what }\end{array}$ & $\begin{array}{c}1 \\
(.3)\end{array}$ & $\begin{array}{c}2 \\
(.5)\end{array}$ & $\begin{array}{c}1 \\
(.3)\end{array}$ & $\begin{array}{c}23 \\
(6.2)\end{array}$ & $\begin{array}{c}66 \\
(17.7)\end{array}$ & $\begin{array}{c}128 \\
(34.4)\end{array}$ & $\begin{array}{c}151 \\
(40.6)\end{array}$ & 6.06 & 1.00 & High \\
\hline $\begin{array}{l}\text { I always find fault } \\
\text { with what the } \\
\text { organization is }\end{array}$ & $\begin{array}{c}112 \\
(30.1)\end{array}$ & $\begin{array}{c}88 \\
(23.7)\end{array}$ & $\begin{array}{c}75 \\
(20.2)\end{array}$ & $\begin{array}{c}63 \\
(16.9)\end{array}$ & $\begin{array}{c}23 \\
(6.2)\end{array}$ & $\begin{array}{c}8 \\
(2.2)\end{array}$ & $\begin{array}{c}3 \\
(.8)\end{array}$ & 5.45 & 1.41 & High \\
\hline OVERALL & & & & & & & & 5.89 & 0.74 & High \\
\hline
\end{tabular}

Sportsmanship was measured by five items. All of the items scored high. The item that scored the highest was "I do not tend to magnify problems" (mean $=6.28, \mathrm{SD}=0.94$ ), while the second was "I always focus on what is right, rather than what is wrong" (mean $=6.06, \mathrm{SD}=$ 1). The third item was "I do not waste time complaining about trivial matters" with mean = $6.04, \mathrm{SD}=1.04$. Meanwhile, the second-lowest item was "I am not the person who likes to complain or protest the loudest attracts attention and service" with the mean $=5.62$ and SD $=1.37$. The item "I always find fault with what the organization is doing [Recode]" (mean = $5.45, \mathrm{SD}=1.41$ ) contributed as the lowest mean in this dimension. Overall, the level of sportsmanship score was high (mean $=5.89, \mathrm{SD}=0.74$ ). This implied that academic staff tolerated less-than-ideal conditions at the workplace, accepted changes in the organization, and performed requests or tasks without grievances. 


\section{Q2. What is the highest domain contributed to academic staff' organizational citizenship behavior in Malaysian Research Universities?}

Table 4 The Level of Organizational Citizenship Behaviors based on Dimensions

\begin{tabular}{lccc}
\hline \hline Dimension & Mean & SD & Level \\
\hline Overall D1: Altruism & 5.72 & 0.81 & High \\
Overall D2: Courtesy & 6.36 & 0.59 & High \\
Overall D3: Civic Virtue & 5.55 & 0.80 & High \\
Overall D4: Conscientiousness & 5.96 & 0.74 & High \\
Overall D5: Sportsmanship & 5.89 & 0.74 & High \\
\hline OVERALL & $\mathbf{5 . 9 1}$ & $\mathbf{0 . 5 6}$ & High \\
\hline \hline
\end{tabular}

Table 4 presents the level of organizational citizenship behaviors (OCBs) as measured by the five dimensions, as stated in the table. This study found that the level of OCBs among academic staff in Research Universities was high. The findings that exhibited the highest level of OCBs belonged to the dimension of courtesy (mean $=6.36, \mathrm{SD}=0.59$ ), followed by the dimension of conscientiousness (mean $=5.96, S D=0.74)$.

Additionally, the dimension of sportsmanship with mean $=5.89$ and SD $=0.74$ showed the third-highest. The lowest two-dimension was contributed by altruism (mean $=5.72, S D=0.81$ ) and Civic Virtue (mean $=5.55, S D=0.80$ ), respectively. Overall, the result implied that the academic staff highly performed the non-tasks as part of their workload as they were keen to do so. The high levels of OCBs showed that academics have discretionary behaviors of helping colleagues, preventing problems related to work among colleagues, volunteering to take responsibility in participation when necessary, as well as tolerating while obeying to the rules and regulations.

\section{Discussion}

This study found that academic staff affirmed OCBs existed substantially in five RUs in Malaysia. All sub-dimensions in OCB had high mean values which were presented by 'agreed' or 'strongly agreed' in the presence of those domains. In general, 'courtesy' appeared to be the most prominent domain in OCBs followed by Conscientiousness, Sportsmanship, Altruism, and Civic virtue, with more than 80 percent of the academic staff agreeing (scale 5 upwards) with these statements. The prominent item for each dimension is discussed as below:

As for courtesy, more than $70 \%$ of the academics agreed with the existence of the items in this dimension. For example, 'try to avoid creating problems for co-workers' was the highest mean in this dimension. This was followed by 'respect the rights of people that work with me', 'take steps carefully to avoid problems with other workers', 'consider the impact of my actions on co-workers', and 'mindful of how my behavior affects other people's job'. Hence, this would reduce intergroup conflicts and decrease the time spent on conflict management activities (Dirican \& Erdil, 2016; Podsakoff et al., 1990). 
For the 'conscientiousness' dimension, it was found that more than seventy-five percent (75\%) of the academics agreed and supported the items in this dimension. For example, items on 'belief in giving an honest day's work for an honest day's pay' and "obey company rules and policy even nobody watching" were the prominent items characterized under this dimension (Dirican \& Erdil, 2016). Thus, the academic staff were proactive and dedicated in performing their tasks out of working hours and formal job requirements.

As for the 'sportsmanship' dimension, more than seventy percent $(70 \%)$ of the academics agreed with the items in the domain. Academic staff were seen as to avoid complaints about trivial matters in the workplace. Academics were not likely to magnify problems, which was presented as the most prominent item with 94.6 percent agreed to this domain. Besides, always focusing on the right side rather than wrong was found to be the next prominent item that characterized academics' thinking and perception on positive matters compared to the negative ones.

As for 'altruism', more than seventy percent (70\%) of academics agreed with the items in the domain. Academic staff's 'willingness to helping their colleagues' and who 'have work-related problems' were the prominent items that characterized the dimension of altruism among themselves in the university community. Thus, the findings of the study were prosperous because it shows that the academics were always ready and enthusiastic to render help to colleagues and people around them at the workplace with open arms (Al-Sharafi \& Rajiani, 2013; Eyupoglu, 2016).

In the dimension of civic virtue, more than seventy-five percent (75\%) of the academics agreed with the item in this domain. For example, the academics were keen to keep abreast of the changes in the organization and keep up with announcements by the organization as the prominent items in the domain. These described their willingness to be concerned and devotedly participate in the organization's programs.

Nevertheless, the survey responses on perceived organizational support indicated a moderate degree of agreement (mean $=4.80 ; S D=1.10$ ). The average response of the academics' perception toward the support provided by the organization regarding appreciation, well-being, care, gratification, and so forth was close to 'somewhat agree'. This result showed that there are still conflicts and lack of organizational support as perceived by the academics in Malaysian Research Universities.

Overall, the result indicated that academics in five Research Universities were proud to be members of the institutions as well as inclined to maintain as its member. As the level of citizenship behaviors was high, it indicated that they were positive in encountering the changes and new orientations that needed them to develop skills and always keep up in learning new things to meet organizational goals and expectations.

\section{Conclusion}

A high level of organizational citizenship behaviors (OCBs) would certainly produce a better performance of individuals and benefit the organizations. Employees who have the attitude of doing things that are beyond their formal job description are expected to go far in their profession (Shanker, 2018; Rose, Miller, and Kacirek, 2016) as they are the ones who envision the organization's goals and continuously look forward to the betterment of the organization. 
To date, a lot of research has been done to improve and escalate the quality of services and performances in higher education institutions, especially in academic staff training. In Malaysia, research on the implementation of organizational citizenship behaviors (OCBs) among academic staff in higher education institutions is quite recent. Therefore, more studies need to be carried out to grasp a better understanding of the complexities of organizational citizenship behaviors in higher education. The effort to improve the OCB of the academic staff should be considered internal and external factors (Shanker, 2018; Sufean \& Chin, 2014). The internal factors come from within the faculty, such as the academic' morals, their satisfaction, desire, and positive attitude with their job and organization. Academics who display exceptional performance and behavior should be acknowledged and encouraged for better performance (Al-Sharafi \& Rajiani, 2013).

Besides, from the theoretical perspective, a more comprehensive model of OCBs is needed to guide future research in Malaysian higher education institutions that correlate OCBs with several predictors, such as trust, job satisfaction, workplace environment, and procedural justice. Future research can also examine these relationships with a broader array of organizational outcomes such as measuring academics' performance as an extended study of their level of OCBs (Kim, Eisenberger, \& Baik, 2016; Preymann et al., 2016).

OCBs of academic staff are important as they are the backbones to the success of the institutions. Therefore, their efforts to perform OCBs are something crucial as these voluntary actions are based on their willingness. Academic staff showed the capacity to perform extrarole behaviors when they stayed in the environment that could enforce them to perform OCBs, especially once they were motivated by the returns they were expected to bring and typically performed from others (Eyupoglu, 2016; Ueda, 2016; Al-Sharafi \& Rajiani, 2013). To know the level of citizenship behaviors of academic staff could help the management party improves the quality of services in higher education institutions.

This study explores the theory of OCBs from various perspectives (Kim, Eisenberger, \& Baik, 2016; Organ, Podsakoff, \& MacKenzie, 2006; Podsakoff et al., 1990) that aimed at generalizing the statements that have been organized and refined at understanding the scenario understudied. The theory of OCBs in this study contributed to the collective of ideas, facts, concepts, and variables that are reasonable, reliable, and consistent with an argument on the cases used to construct it. Contextually, this study contributes to the perspective of behavioral management among academic staff. Furthermore, the research on OCBs in higher education institutions in Malaysia is quite recent. Therefore, the willingness of academics to go beyond the formal duty in accomplishing university's vision, goals, and objectives will definitely contribute to the overall institution's effectiveness. This study is significant to the existing knowledge since OCBs are vital for the sustainability of the organization and positively associated with organizational and workgroup performance. OCBs play a role as a catalyst in empowering academic staff leadership, performance, organizational justice, and commitment. These are aligned with the goals of higher education institutions as to not only anticipate distinguished knowledge and skills but most importantly to provide passionate staff. 


\section{References}

Altbach, P. G. (2013). Advancing the national and global knowledge economy: The role of Research Universities in developing countries. Studies in Higher Education, 38(3), 316330.

Al-Sharafi, H., \& Rajiani, I. (2013). Promoting organizational citizenship behaviour among employees: The role of leadership practices. International Journal of Business and Management, 8, 47-54.

Creswell, J. W. (2014). Research Design: Qualitative, Quantitative and Mixed Methods Approaches (4th ed.). Thousand Oaks, CA: Sage.

Dirican, H., \& Erdil, O. (2016). An exploration of academic staff's organizational citizenship behavior and counterproductive work behavior in relation to demographic characteristics, 12th International Strategic Management Conference: Procedia - Social and Behavioral Sciences, 235, 351-360.

Eyupoglu, S. Z. (2016). The organizational citizenship behaviour of academic staff in North Cyprus. 3rd Global Conference on Business, Economics, Management and Tourism, 39, 701-704.

Gay, L. R., Mills, G. E., \& Airasian, P. W. (2012). Educational Research: Competencies for Analysis and Applications (10 th ed.). Boston: Pearson.

Hair, J. F., Black, W. C., Babin, B. J., \& Anderson, R. E. (2014). Multivariate Data Analysis (7th Ed.). Pearson Education Limited.

Kim, K. Y., Eisenberger, R., \& Baik, K. (2016). Perceived organizational support and affective organizational commitment: Moderating influence of perceived organizational competence. Journal of Organizational Behavior, 37(4), 558-583.

Kline, R. B. (2011). Principles and Practice of Structural Equation Modeling. New York: Guilford.

Nasiibah, R., Zinatul, A. Z., Junaidi, A. A., Hasani, M. A., Jady, H., Hirwani, W. M. H. W. N., \& Yaakob, I. (2013). The concept of Research University: The implementation in the context of Malaysian university system. Asian Social Science, 9(5), 307-317.

Organ, D. W., Podsakoff, P. M., \& MacKenzie, S. B. (2006). Organizational Citizenship Behavior: Its Nature, Antecedents, and Consequences. Thousand Oaks, CA: Sage.

Organ, D. W. (1988). Organizational Citizenship Behavior: The Good Soldier Syndrome. Lexington, MA: Lexington Books.

Podsakoff, P. M., MacKenzie, S. B., Moorman, R. H., \& Fetter, R. (1990). Transformational leader behaviors and their effects on followers' trust in leader, satisfaction, and organizational citizenship behaviors. Leadership Quarterly, 1, 107-142.

Preymann, S., Sterrer, S., Ehrenstorfer, B., Gaisch, M., \& Aichinger, R. (2016). Harmonising the interface between academic and administrative mind-sets: Challenging but feasible? In Global Challenges, National Initiatives, and Institutional Responses (pp. 237-265). Rotterdam, The Netherlands: Sense Publishers.

Rose, K., Miller, M. T., \& Kacirek, K. (2016). Organizational citizenship behavior in Higher Education: Examining the relationships between behaviors and institutional performance. American Association of University Administrators, 31(1),14-27.

Shanker, M. (2018). Organizational citizenship behavior in relation to employees' retention to stay in Indian organizations. Business Process Management Journal, 24(6), 1355-1366.

Sufean, H., \& Chin, W. S. (2014). Organizational citizenship behavior: Its reconceptualization and tenability in university setting. Malaysian Online Journal of Educational Management, 2, 1-20. 
INTERNATIONAL JOURNAL OF ACADEMIC RESEARCH IN BUSINESS AND SOCIAL SCIENCES

Vol. 11, No. 8, 2021, E-ISSN: 2222-6990 @ 2021 HRMARS

Ueda, Y. (2016). Recent trends in organizational citizenship behaviour research: 2010-2015. Japan Society for Promotion of Science (JSPS), 9-41. 